\title{
The Phantom-Limb Pain
}

\author{
by \\ Tetsuya OTSUKA, M.D. \\ Welfare Pension Tamatsukuri Orthopedic Hospital
}

ABSTRACT

$\mathbf{B}_{\text {fectives in upper extremity, } 13 \text { cases defective in lower extremity and } 2 \text { cases }}$ defective in extremities) the following results are obtained.

The phantom-limb is not always accompanied by the phantomlimb pain, whereas the disppearance of phantom-limb does naturally mean the disappearance of phantom limb pain. Since the phantom-limb can be irased by psychological treatment, it is quite possible that the phantom-limb pain can be wiped out likewise.

The fact that the phantom-limb is closely related to the way the phantom-limb pain ocurr seems to corraborate that the motor area is related to the sensory area or cerebral cortex. There is a tendency observed that the phantom-limb pain is more acute in the place where the phan-limb is felt more keenly, than any other place : in the cases of upper extremity defect the nearer the phantom-limb locates to the finger tip, especially that of the thumb, the more acute becomes the pain, and in the cases of lower extremity defect the pain is especially acute in the parts near the first toe of fore foot and the heel. And there is another tendency that an amputee feels strongly the phantom-limb and the phantom-limb pain in the wound received before amputation. The phantom-limb pain and the pain on the amputated stump are of the same nature and both have the characteristics of central pain. It can generally be said that the phantom-limb pain takes precedence over the pain on the amputated stump, but when the phantom-limb with pain is for enough from the amputated stump, the phantom-limb pain and the pain on the amputated stump are felt separately, while in the case that the phantom-limb and the amputated stump are near each other the pains are hardly distinguishable. Two kinds of pain above mentioned are apt to be affected by mental conditions and climate. Conesquently, many of amputees who complain strongly of phantomlimb, phantom-limb pain and pain on the amputated stump often show a psychic sbnormality.

The phantom-limb is reversible; in other words, it is possible that the phantomlimb, which was once disappeared, will re-appear to the patient. And if the enviroment, to which the patient returns, is not satisfactory, the phantom-limb re-appears even to the patient who showed the satisfactory remedial effect of the 
orthopedic exercise including the psychological approach in a hospital or inatitution. Amputees sometimes find themselves having troubles in daily life, when phantomlimb do not correspond with artificial limbs. This fact must be taken into consideration in rehabilitation of patients of irreducible diseases. In other words the patients must be given the psychological reorientation or so-colled "brain washing" according to the conditional reflex throry towards the final stage if recovery of function in their future.

\section{幻肢痛 \\ 大塚 哲 也*}

\section{I. 緒 言}

先に大塚らは四肢切断者と幻肢 (幻覚肢), あ るいは性格などについて発表し，ついでアンケー トにより四肢切断者と疼痛 ${ }^{1 \sim 7}$ の問題にも言及し た。ここでは四肢切断者19例8）（上肢欠損 5 例， 下肢欠損12例，多肢欠損 2 例）について，幻肢の 投影を行ない，とくに幻肢痛（幻覚肢痛）を中心 に検討してみた ${ }^{3) 4}$ (写真 1 )。なお，性格テスト 注小保内, 松岡氏の色彩象徵性格検查を使用し $\star^{9) 10)}$ 。

\section{II. 症例ならびに考按}

\section{症例 1，69歳 우 左肩関節離断(図 1)}

昭和36年11月11日バスの後輪に軪かれ，上肢を 背部に捻じられた形でバスと電柱の間に挾まれ， 即日肩関節の離断手術をうけた。

その後断端部の疼痛が強く昭和 37 年 9 月 29 日本 院入院。10月10日神経腫摘出術および癞痕切除術 施行。昭和38年 4 月 27 日退院した。

幻肢は肩関節離断後より存在し, 背部および前 胸壁に各関節屈曲位のまま密着した形をとってい て，これは約 1 日おきに背部㧍よび前胸壁へと移 動する。な扮背部では捻じられて，しばりつけら れたような感じがする。これは丁度この肢位でバ スと電柱との間に挾まれた形を再現している。ま たこの肢位のときは非常に苦痛を感じるが，前胸

* 厚生年金玉造整形外科病院

（院長 塩津德政博士）医務部長
壁に幻肢がきた場合は掌側が胸壁に接 し楽 であ る。この幻肢の移動は比較的めずらしいが，一応 受傷時の苦痛から逃孔ようとする心理的葛藤の現 われではなからうかと思われる。昭和 37 年12月13 日（神経腫摘出後約 2 力月）性格的に分裂質（異 常+2), 中性, 明暗中性型, 弛緩型9)10) で, 断 端部は㗪痕 $(-)$, 癒着 $(-)$, 神経腫 $(-)$ である。

手術後心理治療を行ない，幻肢の背部および前 胸壁への移動はなくなったが，幻肢は毎日而も常 時存在し, 忘却できない。肩の運動を始めたとき 幻肢をとくに強く感じ。幻肢の肘関節は動く が，腕関節は軽度屈曲位をとり，手指と共に動か ない。ただし上腕神経叢の低周波による刺激で少 乙動く。

幻肢痛核日あり，とくに各手指の先に絞扼感 や「しびれ」感を訴え, 寒さや強い運動を始めた 時に増強する。

断端痛はない。

本症例はこの状態で退院までほぼ同一の状態で 経過した。社会復帰後の経済面の生活は安定して いるが，本人が非常に頑固な性格の持ち主である 事と老人性の精神的および肉体的変化が強い為, 家庭の人達との間に協調性を欠き，また自動車災 害による保障の点とも相まって，心理治療に対し ても碩固に抵抗しており，このような症例では幻 肢の消失には困難を伴う事が分った。

症例 2,21 歳 $\delta$, 右拇指, 示指欠損 (工員, 労 災) (図 2)

昭和38年10月18日混打綿機の調整機械に挾ま 


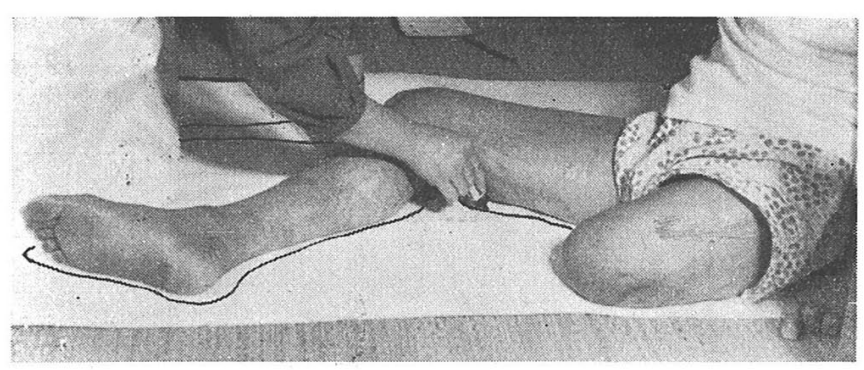

写 真 1

れ，本院で即日切断，11月25日退院した。

11月 8 日性格的に分裂質 (異常 +2 ), 中性, 暗 型, 緊張型で, 断端部は瘏痕 $(+)$, 療着 $(+)$, 神 経腫(一)である。

幻肢は拇, 示指ともに切断前と同大で，毎日常 時存在し, 忘却できない。また幻肢の屈伸も可 能。

幻肢痛は指尖部に「しびれ」感孛訴觉るが，寒 冷時には「じりじり」した感じ，しめつけるよう な痛みが出現する。な竹断端痛は証明されない。

本症例は心理治療を行なわず放置したが, 幻肢 は大院中不変のままであった。

症例 3,25 歳令, 左中, 環, 小指欠損（工員, 労災) (図 3 )

昭和37年 8 月 13 日落盤を゙左手を挫滅, 昭和38年 1 月 18 日入院，1月27日中，環，小指をそれぞれ 切断した。

3月20日性格的に注ヒステリー(異常+1), 中 性, 明暗中性型, 緊張型で断端部は㾹痕 $(+)$, 瘾 着 $(+)$, 神経腫 (一)である。

幻肢は切断前と同大で, 毎日常時存在し忘却で きない。中指と環指は癒着しており, 各幻肢の屈 伸運動は可能である。

幻肢痛は夜間時々指尖部に「しびれ」感, 「か ゆみ」を感じる。

断端痛はちょっと触れると, 強い刺激を感じ, 普段でも手を使い過ぎると痛むが放置している。

義手は幻肢の為装着が障害となる。

本症例も放置したままで経過を観察したが， 入 院中変化はとくに証明されなかった。

症例 4 , 38歳令, 左中指欠損 (工員, 労災)

(図 4)

昭和38年 9 月14日紙を切る機械で中指を切断。
10 月 1 日入院。昭和39年 1 月 21 日退院。

11月5日性格的に神経質(異常十 1), 中性, 明型, 弛緩型で断端部は瘏痕 (一), 癒着 $(+)$, 神経腫 $($ - )である。

幻肢は存在しない。

断端痛はときどき刺痛,「しびれ」感, 「ピリピリ」する痛みを訴えるが，痛み の程度はいつも同じで，マッサージを行 なう事により軽快する。なお退院時には ときどき刺激痛を訴える程度になっている。 症例 5,21 歳令, 左示, 中, 環指灾損（工員, 労竾) (図5)

昭和38年 4 月26日機械に挾まれて，示，中，環 指学即日切断, 9 月 9 日入院。

来院時の性格は神経質 (異常 +1 ), やや男性的, 明型, 繁張型で断端の状況は瘏痕 (-), 癒着 $(+)$, 神経腫(ー)である。

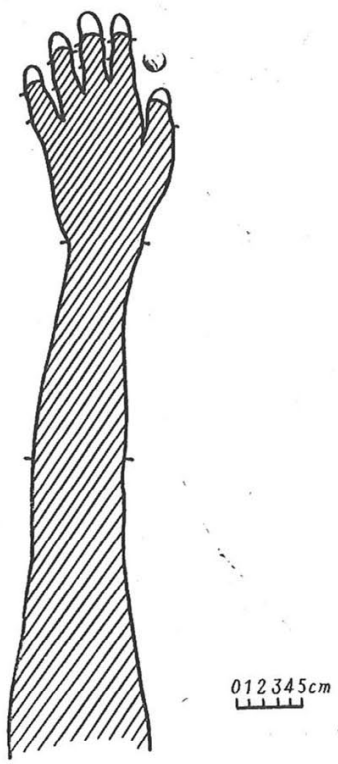

図 1 症例 1, 69歳 $。$, 右有関節離断 性格: 分裂犋 (異常 +2$)$, 中性, 明惕中性型, 弛緩 型幻肢痛: 手指尖（䜌扼感, しびれ感) 断端痛：なし

幻肢は存在しない。

断端痛は示指と中指に「びりびり」「じりじり」 した感じ，および「しびれ」感を訴え，これは寒 冷時や物をつかんだ時より強く感じる。なお環指 は刺痛だけを感じる。これら疼痛に対してはいず 

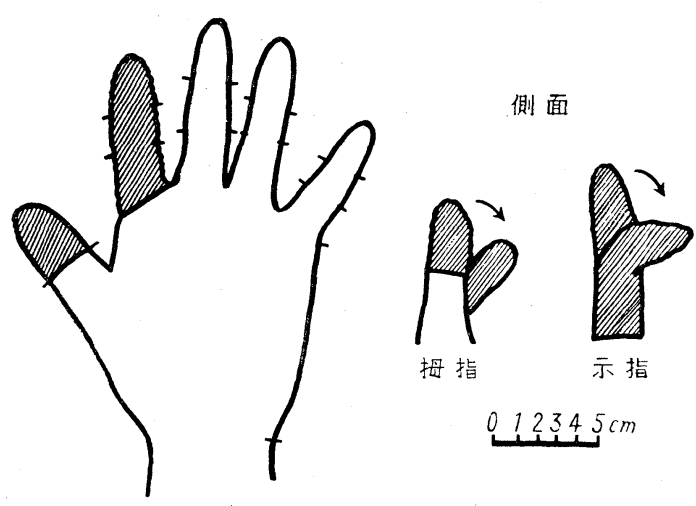

図 2 症例 2，21藏む，右拇手指欠損 性格: 分裂質 (異常+2), 中性, 暗型, 緊張型 幻肢痛：指尖部（しびれ感）

断端痛：なし

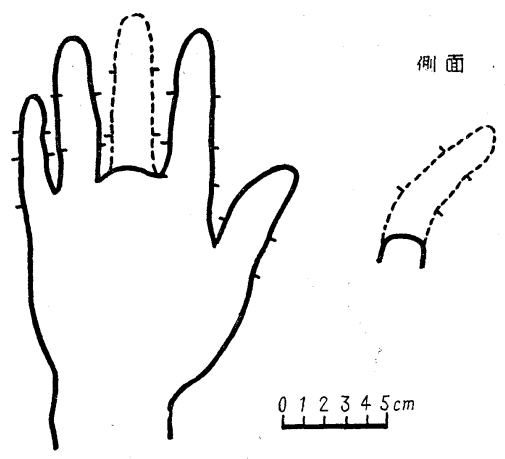

図 4 症例 4 , 38歳今, 左示指欠損

性格: 神経質 $($ 異常 +1 ), 中性, 明型, 弛緩型 幻肢：なし

断端痛 : 刺痛，しびれ感，ぴりぴりする痛み

れも放置している。

症例 6, 69歳 早，右大腿欠損（農業，国保）

(因6)

昭和36年12月26日アスファルトの上に転倒した 事がある。昭和 37 年 2 月頃より右膝関節部に鈍痛 を訴えるようになった。7月16日組織標本により 右脛骨肉腫である事が分かり，8月16日本院入 院。8 月27日大腿切断。9月19日退院した。

9 月 5 日性格的に神経質(異常+2), 中性, 明 型, 弛緩型で断端部は瘢痕 $(-)$, 痛着 $(-)$, 神経 腫(一)である。

幻肢は切断前と同大で毎日常時存在し, 忘却で きない。幻肢は肌色の色彩を帯びており，幻肢は 自由に動かす事ができる。

幻肢痛は常時「しびれ」感と「ちかちか」する

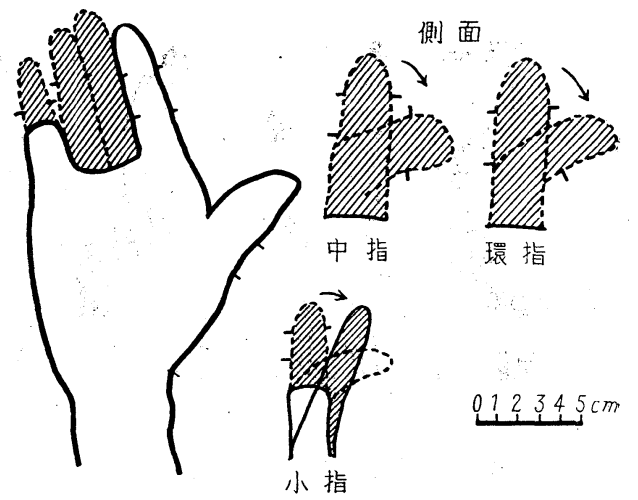

図 3 症例 3, 25歳今, 左中環小指欠損

性格：ヒステリー(異常十); 中性, 明暗中性型, 緊張型

幻肢痛：指尖部（しびれ感，かゆみ）

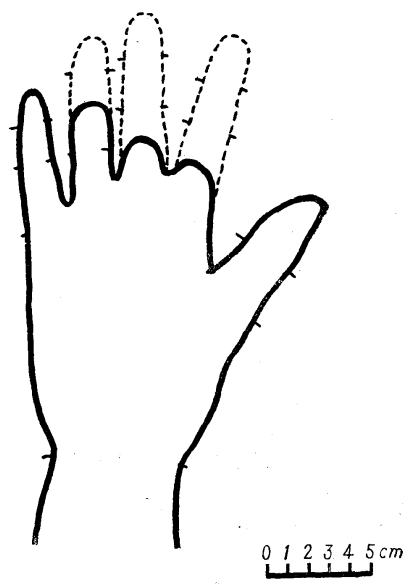

図 5 症例 5,21 歳 0 , 左示中環指欠損 性格: 神経質 $($ 異常 +1 ), やや男性的, 明型, 緊 張型

幻肢：なし

断端痛：示中指(びりびり，じりじり)，環指（刺 痛)

感じを訴え，これは趾先に強く，また踝趾側に近 づく程強い。

断端痛としては断端部に「熱い感じ」が毎日あ り，また「しびれ」感は夜間に増強する。また， ときどき電撃痛,「ビりごり」「ぴりぴり」する感 じ，および絞捃痛を訴えるが，これらは物事に熱 中すると忘れる。夢では健康なもとの身体になっ て歩行した夢を 3 回程みている。

本症例では心理治療を行なわなかったが，幻肢 は不変, 疼痛を去るためしばしば鎮痛剂（アバピ ラ，セデス，ブロバリンなど）を使用しており， 


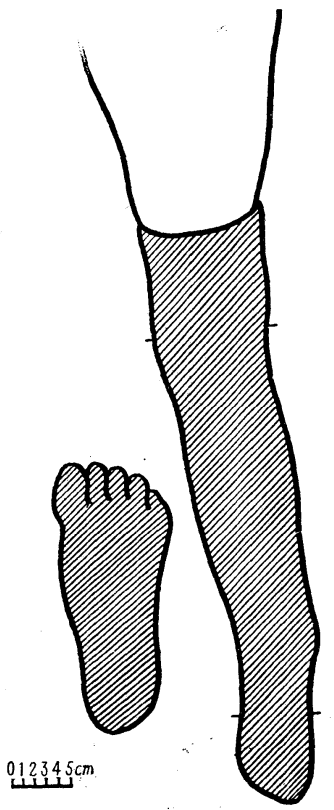

図 6 症例 6,69 歳 9 , 右大腿欠損

性格: 神経質 (異常 +2$)$, 中性, 明型, 弛緩型 幻肢痛: 趾先（跬趾側程強い）（しびれ感, ちか ちかした感じ) ぴりぴり，絞把痛

薬物中毒に陥る危険性を多分に持っているので， 本症例のごときは幻肢の消失を計る事が必要であ 万う。

\section{症例 7, 53歳令, 左大腿欠損 (農業, 生保)}

(図 7 )

昭和29年自動車のガソリンに引火儿, 全身火傷 をうけ，また左下腿部に難治性潰瘍を残した。

昭和38年 1 月初旬頃よりその肉芽組織の異常増 殖に気づき，6月21日本院へ入院。組織標本より 皮膚癌である事が分かり，6月25日大腿切断を行 なった。

7 月21日性格的に神経質 (異常+3), 中性, 明 型, 弛緩型で, 断端部は瘢痕 $(-)$, 癒着 $(-)$, 神 経腫(一)である。

幻肢は切断前と同大で毎日, 常時存在し, 忘却 できないが，自分の意志で自由に動かす事はでき る。また幻肢を桃色に感じる。

幻肢痛としては公肢全体に重圧感と刺痛を感じ るが，絶えずその訴える場所が移行しているが， 幻肢の膝関節を屈曲すると幻肢痛は消失する。ま たときどき電撃痛を訴える事がある。

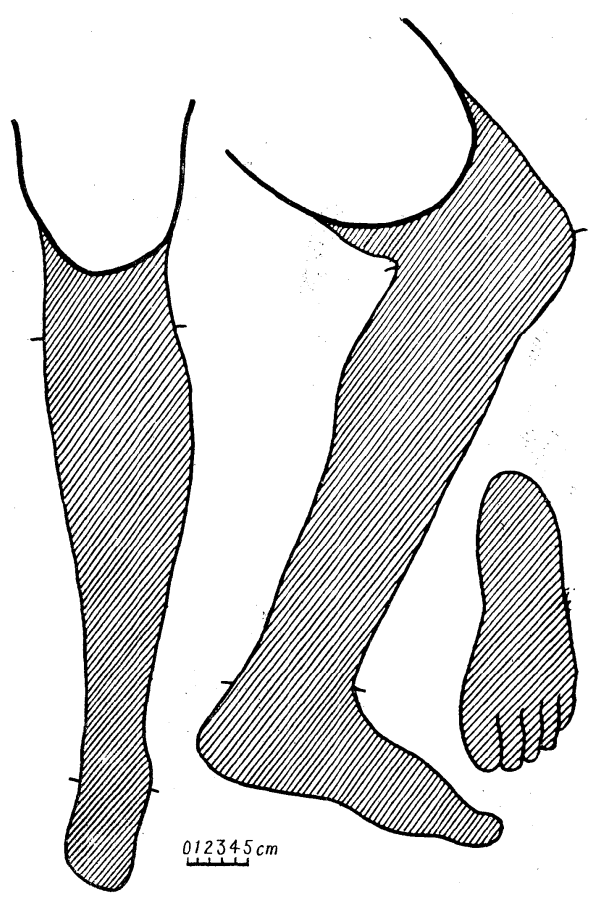

図 7 症例 7, 53歳古, 左大腿欠損 性格：神経質 (異常 +3$)$, 中性, 明型, 弛緩型 幻肢痛：全般に重圧感と刺痛，時々電撃痛 断端痛：しびれ感, ぴりぴりした感じ。時々電撃 痛, 膊動痛, 錐でもむ痛み, 灼熱痛, 痙攣痛, 絞扼痛, 圧痛

断端痛は切断面全般にわたり「しびれ」感を訴 え，手術創に触れると「ひきさく」ような痛みや 「ぴりぴり」した痛みを訴える。その他ときどき 電撃痛, 膊動痛, 錐でもむような痛み, 灼熱痛, 痤攣痛, 絞扼痛, 圧潰痛などの高度の疼痛を訴え ている。本症例は確かに性格的には異常であるの で, 疼痛内容も非常に豊富である。その後心理治 療を含む整形外科機能訓練を行なう事により，3 カ月後に幻肢を一応消失させた。この時性格的に は神経質 $($ 異常 +1$)$, 中性, 明型, 緊張型となっ ていた。幻肢の消失に伴い, 当然幻肢痛は消失 し, 一方断端痛も圧迫により刺激を訴える程度に なった。このように疼痛には心理面も大いに関与 している点も見逃せない。

なお本症例では心理治療中, 義肢装着あるいは 断端部の圧迫により幻肢が出現あるいは延長する 傾向がある事に「ヒント」を得て, 幻肢の一応消 失した後, 条件反射の理論により, 義肢装着時に は幻肢が出現し，しかも義肢と幻肢とが一致し， 


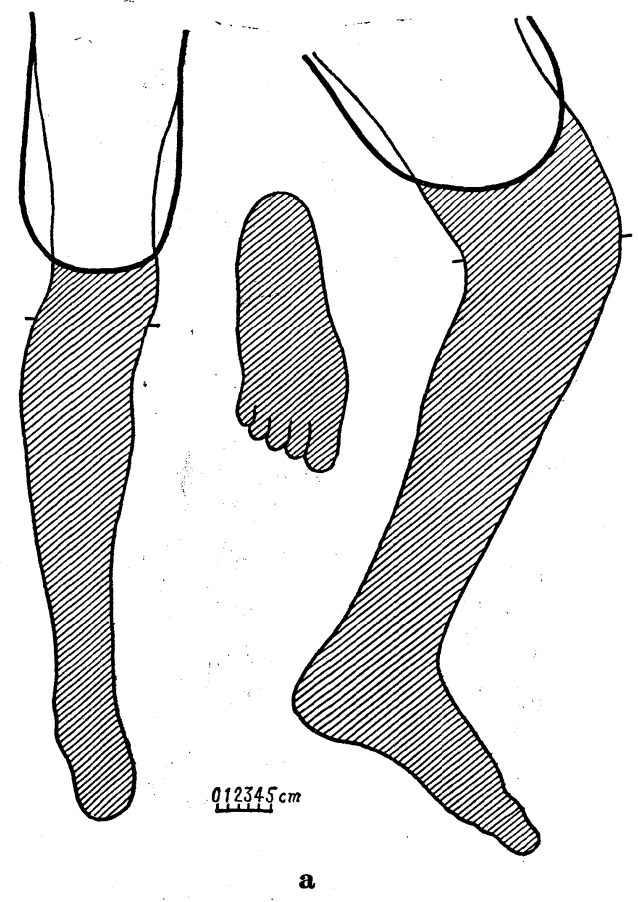

図 8 症例 8,27 祡 0 , 右大腿欠損

a. 性格：ヒステリー (異常+2), やや男性的, 暗型，弛緩型

幻肢痛：なし

断端痛：しびれ感，じりじり針で刺すような痛 み

b．幻肢痛：なし

断端痛：つき刺すような痛み

c. 幻肢痛：足趾にしびれ感（拇趾側程強い）, 足 趾の踣側には時々電撃痛

断端痛：なし
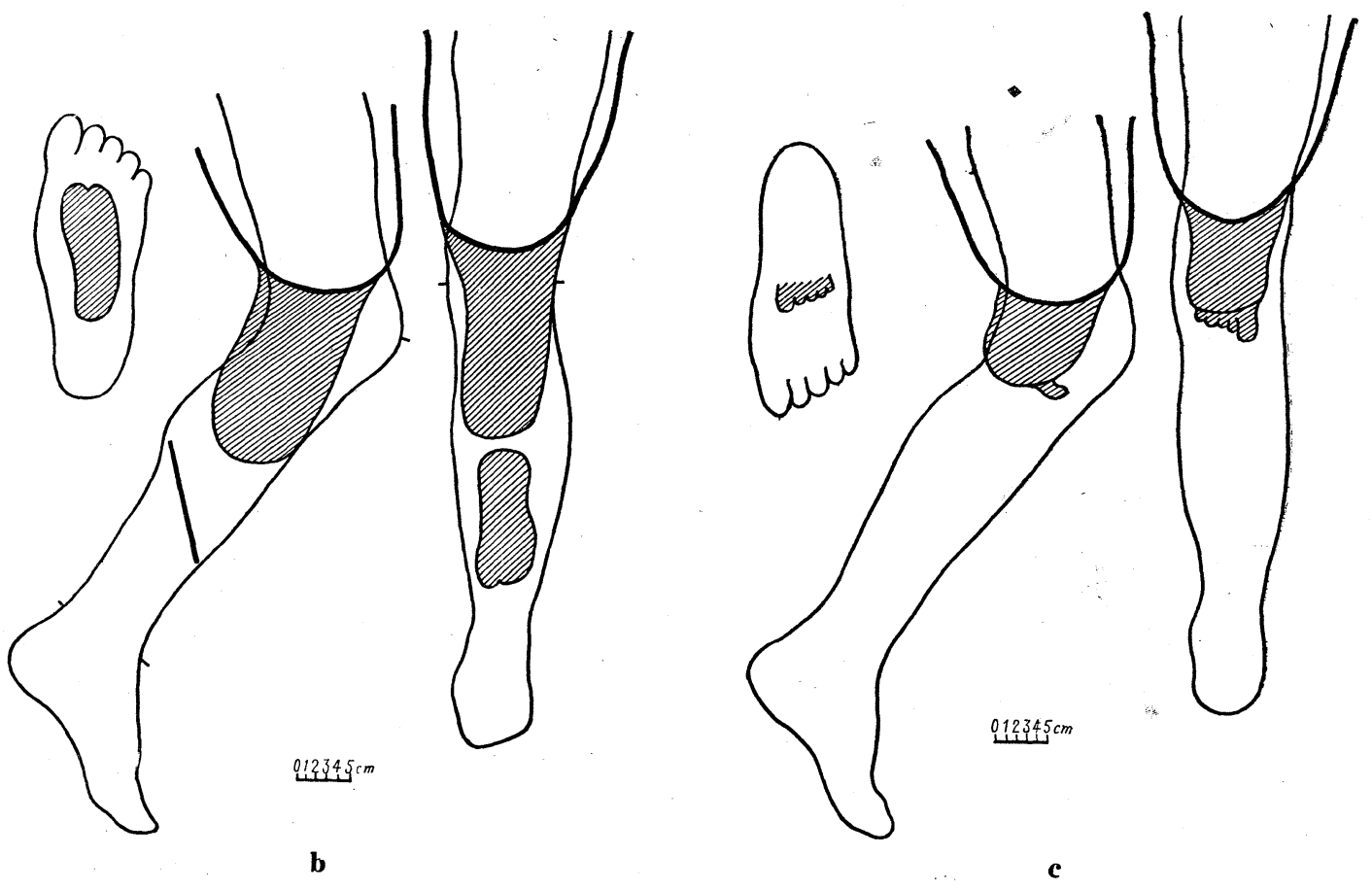


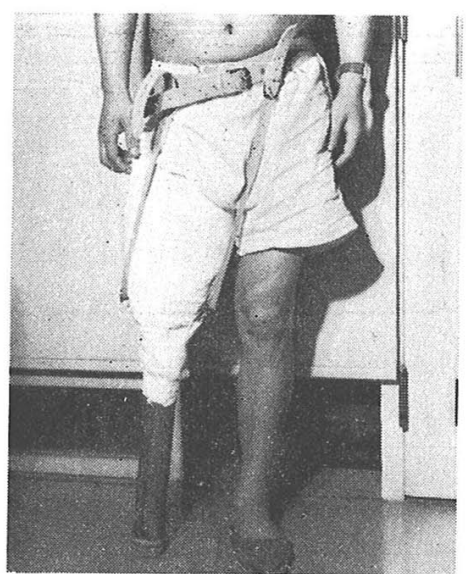

写真 2 症例 8 の正面

義肢を除くと幻肢は消失するといら心理治療を行 なったところ，一部成功した。一般に上肢欠損と 異なり，下肢欠損では幻肢と義肢とが一致すると， 日常生活上非常认有利な場合が少なくないので， このような事を考慮に入れて各症側に応じて心理 治療を試みてみるのもよいのではなかろうか。

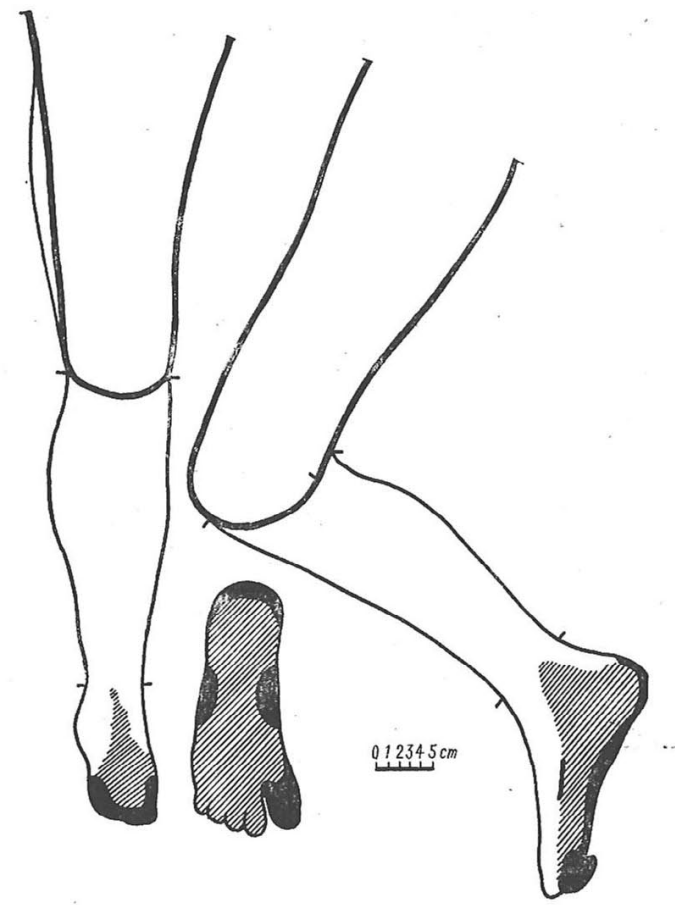

図 9 症例 9, 59歳 8 , 右滕関節離断 性格：躁うつ質 (異常+1), やや男性的，明暗中 性型, 毉張型

幻肢痛：足底部全般（絞把痛）, 踵部（時々刺痛） 断端痛 : 刺痛

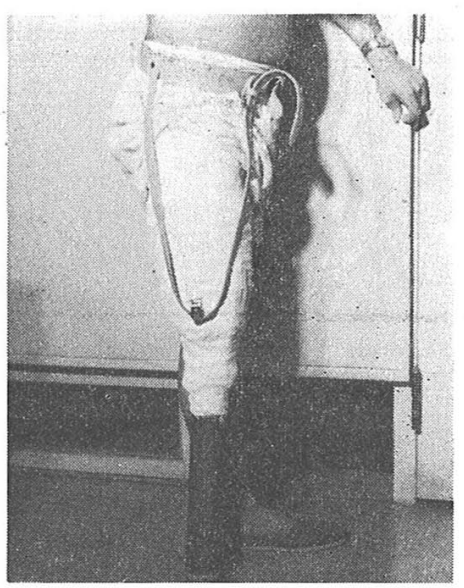

写真 3 症例 8 の側面

症例 8,27 歳今, 右大腿欠損 (船員, 船保) (図8一个, 口, 八)

昭和 37 年 12 月 2 日船のワイヤーに右大腿部を巻 き込まれ，2 日後切断された。昭和38年 1 月 4 日 本院へ入院。7月24日退院した。

5 月10日性格的にはヒステリー (異常十 2), や や男性的, 暗型, 弛緩型で断端部は瘢痕 $(-)$, 癒

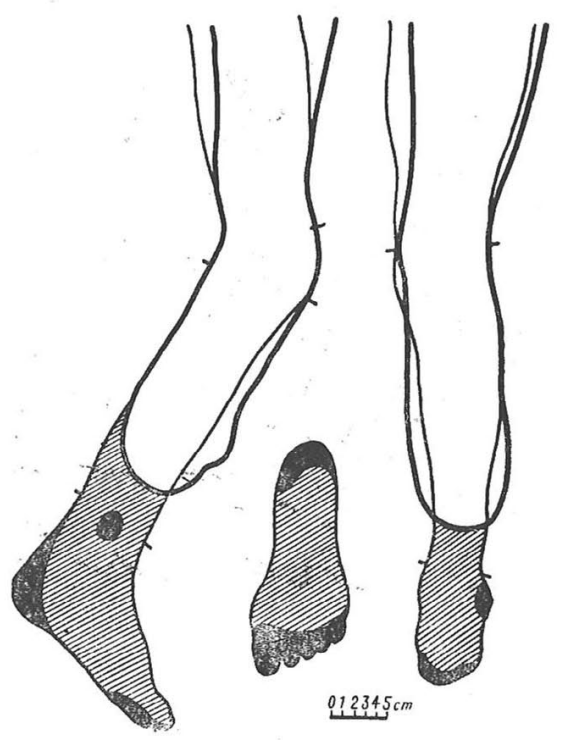

図10 症例10，44歳 $\hat{O}$, 右大腿欠損 性格 :テスト行なわず

幻肢痛: 足底部全般, 踵部 (刺痛), アキレス腱 部 (時々電撃痛)，足尖部拇趾側程強いしびれ感 断端痛: ( 


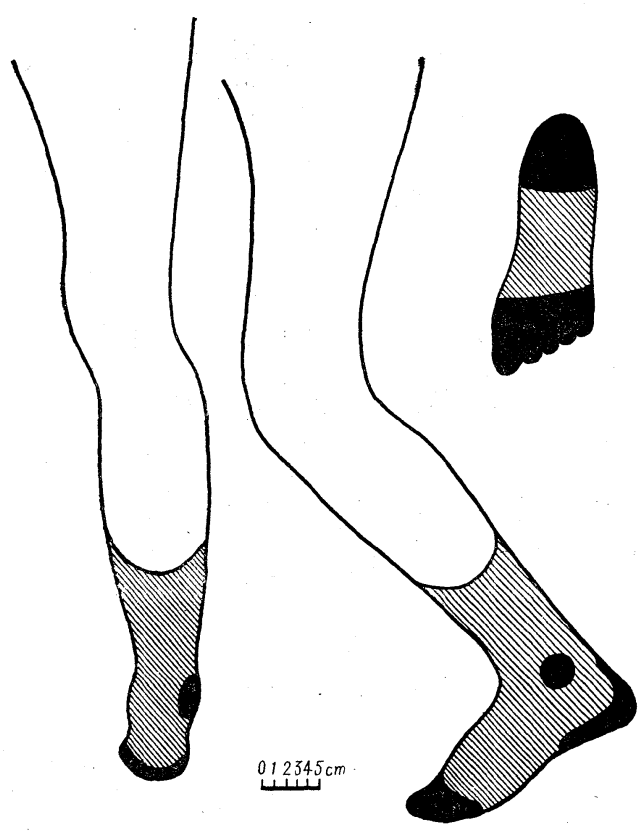

図11 症例 11,42 歳 む, 右下腿欠損 性格: 分裂質 (正常), 女性的, 明暗中性型, 弛緩 型幻肢痛：踵部, 前足部 ((しびれ感) (拇趾側程

強い) 時々電撃痛), 内踝部 (もとの潰瘍部) ち くちくする痛々

断端痛：刺痛，ちかちかする痛み

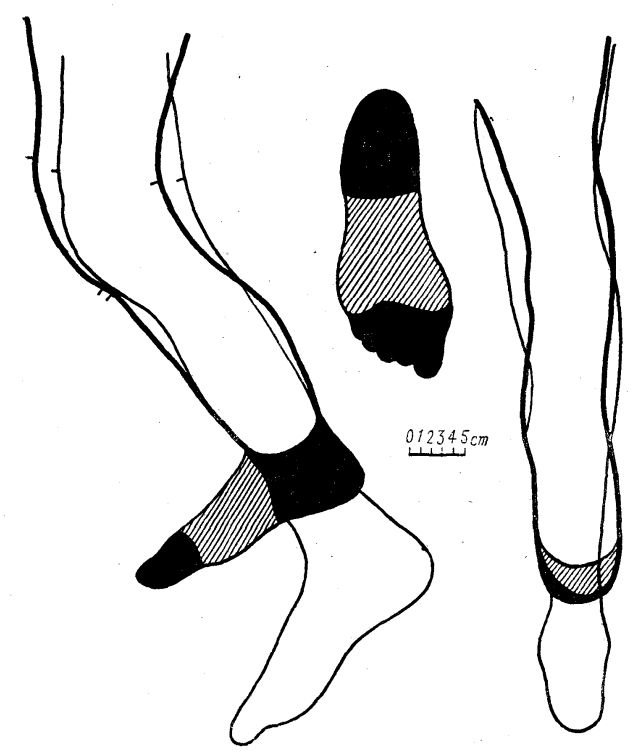

図12 症例 12,31 歳 $₫$, 右下腿欠損

性格: 躁うつ質 (異常+3), 中性暗型, 緊張弛 緩対立型

如肢痛：踵部, 前足部拇趾側程強い（しびれ感,

じりじり，びりぴりする感じ)

断端痛: 電撃痛
着(一), 神経腫 (一)である。

幻肢は切断前と同大で, 毎日常時存在し, 忘却 できない。

本症例は入院後ギプスと竹による仮義足（写真 2，3）で歩行練習を行なっていたが，この幻肢 のため, 仮義足装着は非常に不便を感じると訴え ていた。なお幻肢痛はない。

断端痛は断端部を中心に、「じりじり」と針で刺 すような痛みと，しびれ感を訴えている。

したがって心理治療により幻肢の消失を計った が，1力月後(因8一-口)，2 力月後(図8一八) と次 第に幻肢は消失して行き, 退院時 (約 2 力月半後) にはまったく消失した。

一方疼痛面では 1 力月後 (因8一ロ) には断端部 に「つき刺す」ような痛みを, また 2 力後（図 8一八）では幻肢の足趾にしびれ感を訴え，しか も践趾側程強く, また跁趾の蹠側には時々電撃痛 を訴えている。

幻肢の消失とともに幻肢痛も消失, 断端痛もま た消失した。

症例 9,59 歳令, 右膝関節離断（製材業, 厚生 年金) (図9)

昭和37年9月24日, ベルトに右下腿を巻き込ま れ, 即日膝関節を離断された。昭和38年 5 月 14 日 本院一入院。5 月20日神経腫摘出術, 6 月 29 日退 院した。

5 月30日性格的に躁うつ質 (異常+1), 男性的, 明暗中性型, 緊張型で, 断端部は瘢痕 $(-)$, 癒着 (一)，神経腫 (一)である。

幻肢は不動で足部が部分的に遊離し, 毎日常時 存在し, とくに践趾は底屈している。また幻肢の 忘却は普段はできないが，新聞を読んだり，ラジ オを聞いている間は忘却している。

幻肢痛は足底部全般に絞扼痛を, また踵部には ときどき刺痛を訴える。これは雨天時, 寒冷時, 気分のいらいらした時には増強する。

断端痛としては手術創の圧迫により刺痛を訴え る程度に過ぎない。なお有痛時には断端部をマッ サージしている。なお幻肢は心理治療により約 1 カ月で消失した。

本症例のごとく疼痛注心理的不安, 天候などに より影響される事が分かる。また夢ではもとの状 
態となって歩行した夢をしばしばしばみている。 保険は厚生年金であるので，本人は今後の処置も この厚生年金でできるという事と社会復帰しても 経済的に安定 (製材業) しているので安心だとい っている。このように社会復帰への安心感は整形 外科機能訓練を始め, 心理指導あるいは疼痛の克 服にも好影響を与えるものであって，これが治療 面に果たす役割はきわめて重要なものといえる。

症例 10,44歳令, 右下腿欠損（船員, 船保) （図10）

昭和38年 1 月 17 日木材に右下腿を挾まれ, 開放 性の複雑骨折を起こし, 即日下腿切断を受けた。 4 月 1 日本院一入院。4 月19日断端形成術施行。 7 月26日退院した。

幻肢は入院時ほとんど切断前と同大で, 毎日常 時存在し, 忘却できない。断端部は㓔痕 $(+)$, 癒 着 $(+)$, 神経腫 $($ - ) である。

幻肢痛は踵部に刺すような痛み，足底部全般に 「しびれ」感を訴え, しかも足尖部で踝趾側に近 づく程その程度が強い。またアキレス腱部にも時 々電撃痛を訴えている。しかし断端痛はない。

本症例も断端形成術と同時に心理治療を行な い, 約 3 週後に幻肢と共に幻肢痛も消失した。本 人は寮長として復職も可能で, 職業的にもまた家 庭的にも心配なく社会復帰ができるといってい る。

\section{症例 11, 42歳 ㅇ, 右下腿欠損 (主婦, 国保)} (因11)

8 歳の時左足関節捻挫後踵骨々髄炎を併発し, 難治性潰瘍を作る。昭和38年10月 8 日本院へ入 院。組織標本より肉腫である事が分かり，11月17 日下腿切断を行ない，昭和 39 年 1 月 30 日退院し た。

昭和38年11月25日性格的に分裂質 (正常) 女性 的, 明暗中性型, 弛緩型で, 断端部は痏痕 $(-)$, 療着 $($ ( ) , 神経腫 $($ - ) である。

幻肢は切断前と同大で, 毎日, 常時存在し, 忘 却できない。しかし自分で自由に動かす事はでき ない。幻肢は踵部と前足部にとくに強く感じら れ, しかも足尖部では跬趾側に近い程強くなる。 またこの部に一致して「しびれ」感を訴えてい る。

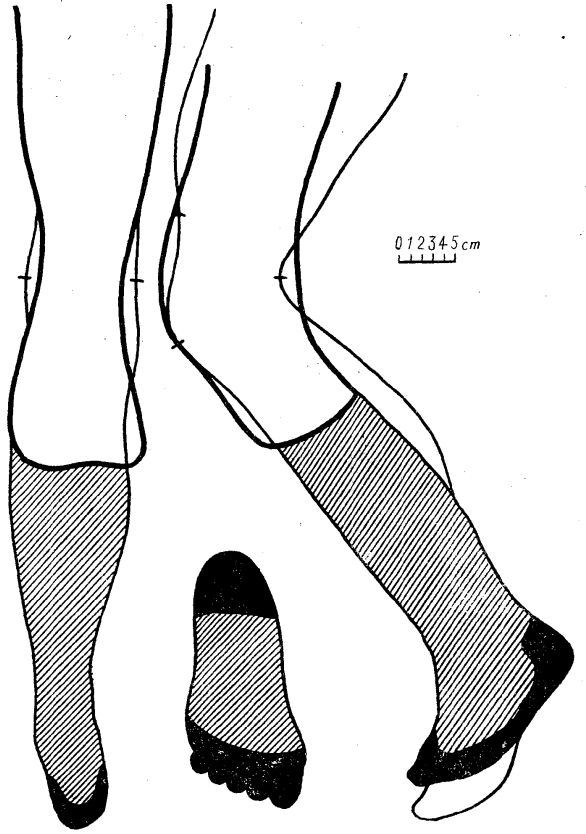

図13症例 13,10藏。, 左下腿欠損 性格：躁うつ質 (異常+3), 中性, 明型, 緊張型 幻肢痛：踵部, 前足部, 拇趾側程強い（づきづき する痛み，膊動痛，校拒痛）

断端痛 : 刺痛

また別に内踝部に接して幻肢を強く感じるとこ ろがあり，この部は丁度難治性潰瘍のあった場所 に一致しており，ここにときどき電撃痛や「ちり ちり」する痛みを訴える。

断端痛に刺痛や「ちかちか」する痛みを感じる が，幻肢痛の方が強いためあまり気にならないと いっている。

本症例では幻肢痛と断端痛とは明らかに区別で きており，しかも幻肢痛の方が断端痛に優先して いる事が分かる。また難治性潰瘍部の幻肢がとく に強く残っている点に注意を要する。本人は退院 後の生活はまったく安定しており，心理治療によ り約 2 力月で幻肢, 幻肢痛および断端痛もそれぞ れ消失した。

症例 12,31歳令, 右下腿欠損 (工員, 労災) （図12）

昭和37年10月 6 日工事中約 $15 \mathrm{~m}$ の高さから転 落, 右足部の開放性骨折と左大腿骨骨折を起こ し，右足部は化膿した。12月27日本院へ入院。数 回の手術を行なったが，壞死となったため，昭和 
38年10月31日右下腿切断を行なった。

11月14日性格的に躁うつ質(異常+3), 中性, 暗性, 緊張弛緩対立型で断端部の状況は瘢痕 $(-)$, 装着 $(-)$, 神経踵(一)である。

幻肢は毎日常時存在し，忘却できない。幻肢は 短縮し，幻肢の足部が切断に密着している。

幻肢注踵部と前足部とをとくに強く感じ，また 同時に踝趾側に近づくにつれて強くなる。幻肢痛 としてこの幻肢の強い部分に一致して，「じりじ り」「びりびり」する感じ，「しびれ」感を訴える が，放置している。

断端痛としては断端部にふれると電撃痛を訴え る。

昭和39年 2 月 30 日仮義足装着と同時に幻肢は完 全に消失したが，断端部に触れるとなお電撃痛を 訴える場合には疼痛の強い幻肢痛の方が優先する ため，断端痛は幻肢痛のしたにかくされ，したが って幻肢痛と断端痛との区別が困難となっている のではないかと考えられる。

\section{症例13，10歳合，左下腿欠損（生保，国保）}

昭和38年 7 月26日バスに軪かれ，左下腿挫滅開 放骨折を起こし，本院一入院したが，創面が化 膿, 壊死に陥ったため 2 週後左下腿の切断をう け，昭和38年12月27日退院した。

昭和38年 9 月 4 日性格的に躁 うつ質 (異常+ 3), 中性, 明型, 緊張型で断端状況は瘏痕 $(-)$, 瘾着 $(-)$, 神経踵 $($ - $)$ である。

幻肢は切端前と同大で 3 日に 1 回の割で出現 し，幻肢は不動で物事に熱中すると忘却できる。 とくに運動がはげしい時, 疲れた時に出現しやす w。

幻肢は踵部および前足部で，しかも跁趾側に近 くなる程強く感じる。ここに一致してづきづきす る痛み, 膊動痛, 絞抳痛などの幻肢痛を訴える。 また開放骨折を起こした場所にも幻肢を強く感じ ている点に注意を要する。

断端痛としては切断端に触れた時にのみ刺痛を 感じる程度である。

本症例は心理治療を含む整形外科機能訓練を行 ない, 約 3 週後で幻肢, 幻肢痛および断端痛も消 失した。この時の性格的には神経質(異常+1), 男性的, 明型, 緊張型となっている。

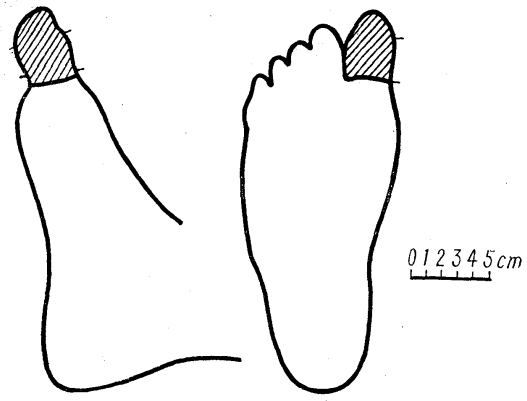

図14 症例 14,50 歳 $\hat{0}$, 左拇趾欠損 性格：躁うつ質（正常）, 男性的, 暗型, 弛緩型 幻肢痛：全般にしびれ感，じりじりした感じ 断端痛：しびれ感，じりじりした感じ

本症例のごとく年少者では比較的容易に心理治 療に反応寸る事が分かる。

症例 14,50歳令, 左䟤趾欠損 (鉄道, 公傷)

(図14)

昭和38年 8 月 11 日レールと枕木に左践趾を挾ま れ, 開放骨折を起こし，8月17日入院。血行障害 のため, 壊死に陥り，8月26日左跁趾切断，9月 18日義足装着，10月26日退院した。

9 月 5 日性格的に躁うつ質 (正常), 男性的, 暗 型, 弛緩型で, 断端部は瘏痕 $(-)$, 療着 $(-)$, 神 経腫(一)である。

幻肢は切断前と同大で毎日，常時存在し，自分 の意志で動かせないし，また忘却もできない。 幻肢痛は幻肢全般に「しびれ」感と「じりじり」 した感じを訴え, 断端痛も幻肢と同様, 「しびれ， 感」と「じりじり」した感じを訴えているが，は っきり区別する場は困難である。

本症例は義足と幻肢が一致して，日常生活には 便利である。

症例 15, 49歳令, 左第 4, 5 趾欠損 (工夫, 労" 災)（図15）

昭和38年 7 月 15 日架橋中, 橋げたが落下し, 左 第 4，5趾の開放性粉砕骨折を起こした。血行障 害により壊死になったため，8月5日左第 3 およ び第 5 趾を切断し，11月30日退院した。

9 月 10 日性格的に神経質 (正常)，中性，暗型， 弛緩型で, 断端部に瘏痕 $(-)$, 癒着 $(-)$, 神経腫 (ー)である。

幻肢は切断前と同大で毎日，常時存在し，自由 


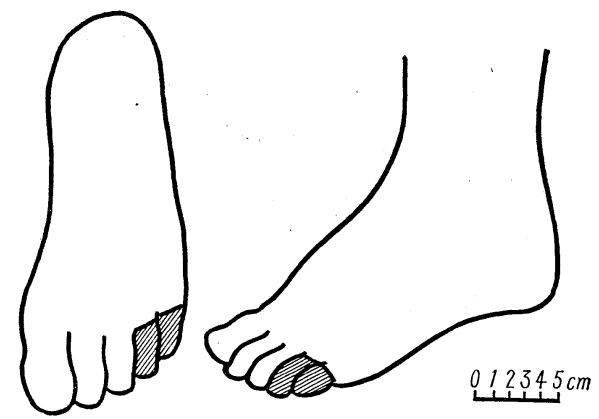

図15症例 15,49 歳 $\delta$, 左第 4, 第 5 趾欠損 性格: 神経質 (正常), 中性, 暗型, 弛緩型 幻肢痛：全般にしびれ感 断端痛：しびれ感

に動かせない。幻肢は歩行時に強く感じ，反対に 新聞をを読んだり，ラジオを聞いているときは忘 却している。

幻肢痛は幻肢全体に「しびれ」感を訴え，また 断端痛としても「しびれ」感で，幻肢痛と断端痛 と同じように感じて，とくに厳密に区別できない という。心理治療により約 3 週間で幻肢および幻 肢痛は消失したが，断端痛は圧迫により「しびれ」 感を訴える程度である。この時の性格は神 経質 (正常), やや男性的, 明型, 緊張型である。

以上でも分かるように足趾切断では践趾側程幻 肢も幻肢痛も強く感じる傾向が強い事が分かり， またこのように短かい切断の場合には，幻肢痛と 断端痛の区別が困難となるようである。なお幻肢 および幻肢痛, 断端痛の消失とともに性格的にも 正常となり，明るい性格，積極的性格になってく る事にも注意を要する。

症例 16,53歳令, 左大腿欠損（郵便, 共済)

(図16)

10歳の時, 左脛骨々䯣炎に罹患, 再発を繰り返 し, 難治性潰瘍を残した。昭和 37 年10月頃より潰 瘍部に悪臭を発するようになり，昭和 38 年 4 月 8 日入院。組織標本により皮膚癌である事が分か り，5月 6 日左大腿部切断を行なった。

幻肢は切断直後より 3 日間, 排便, 排尿時にあ っただけで，その後は完全に消失している。

5 月22日性格的に神経質(異常+3), 中性, 明 暗対立型, 緊張弛緩対立型で, 断端部は誐痕 $(-)$, 癒着 $(-)$, 神経腫 $($ - ) である。

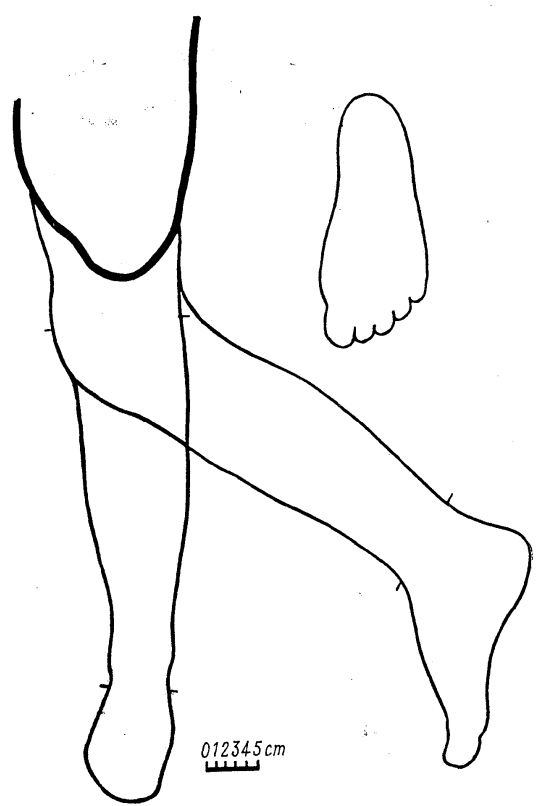

図16 症例16,53歳古, 左大腿欠損 性格: 神経質 (異常＋3), 中性, 明暗対立型, 緊張弛緩型

幻肢：なし

断端痛：なし

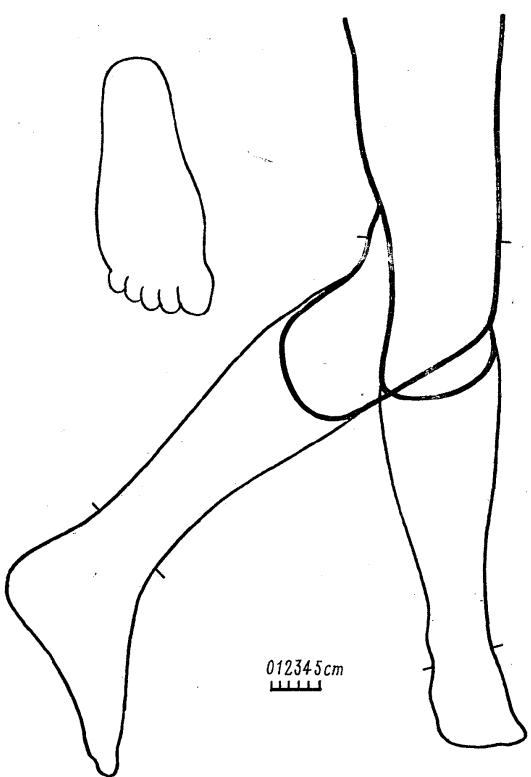

図17症例 17,44 歳。，右大腿欠損 性格：分類質（異常+1），やや男性的，明型， 緊張型

幻肢痛：なし

断端痛：なし 
また断端痛はない。

本症例のごとく慢性疾患で自然に用廃の状態に 近づいて行くような場合，中枢神経系への映像が うすくなるため，幻肢は容易に消失し，また出現 乙難いものと思われる。

11月9日より整形外科機能訓練を開始。性格的

a.

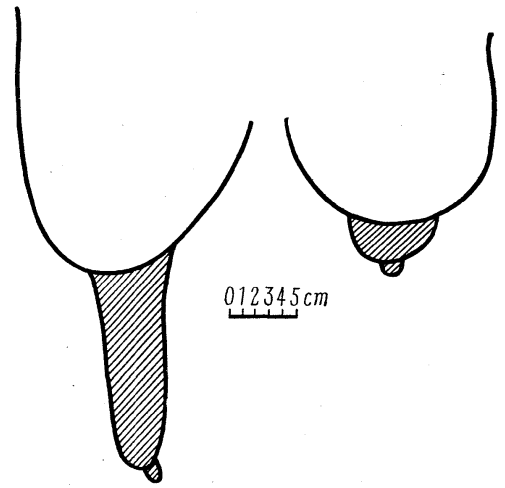

b.

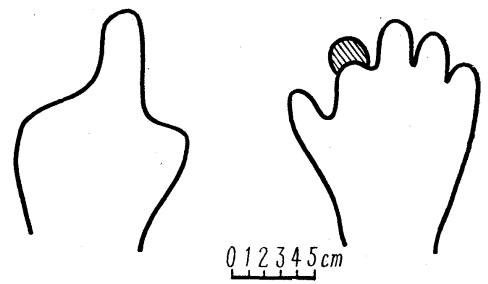

図18症例18，48歳古，両手指欠損両大腿欠損

a. 性格：ヒステリー (異常+1), 中性, 暗型, 緊張型

幻肢痛：右側全般にじりじりした感じ

断端痛：なし

b. 性格 : ヒステリー（異常+1), 中性, 暗型, 緊張型

幻肢痛：なし

断端痛：なし

にはてんかん質(異常+1)，やや男性的，明型， 緊張型で，12月11日より義足を装着。性格的には てんかん質 (正常)，男性的，明型, 緊張型となり， 性格が正常化し，明るくかつ積極性の方向に変化 してきている事が分かる。

すなわち切断当初は性格的に異常状態である事 は容易に理解できるが，心理治療を含む機能訓練 により，本人に自信がついてくれば，性格も正常 化してくる事に注意しなければならない。

症例17，44歳令，右下腿欠損（工員，労災）

(図17)
昭和38年 2 月 22 日右下腿を機械に挾まれ，右下 腿を即日切断された。7 月9 日本院へ入院。11月 21日義足を装着し，整形外科機能訓練を開始，12 月20日退院した。

幻肢は切断後 2 力月間で消失。

入院時の性格は分裂質 (異常+1), やや男性的, 明型，緊張型で，断端部は瘦痕 $(-)$, 癒着 $(-)$, 神経腫 $($ - )である。

断端痛はない。

退院時の性格はてんかん質 (正常)，男性的，明 型，緊張型で性格的には安定した状態である。

症例 18, 48歳占, 両大腿欠損, 両手指欠損（厚 生年金)（図18一a， b )

特発性脱疽のため，昭和 25 年 5 月両下肢の股動 脈の交感神経切除術施行，昭和26年12月右足部切 断, 昭和 27 年 12 月右下腿切断, 昭和 35 年 3 月左大 腿切断，昭和35年 9 月 29 日本院一入院。

昭和36年 7 月左拇指切断，昭和 37 年 6 月右示指 切断, 昭和 37 年 7 月右大腿切断, 昭和 37 年 11 月右 中，環，小指切断，昭和37年12月左示，環，小指 切断した。

昭和38年 6 月 11 日性格的にヒステリー（異常十 1), 中性, 暗型, 緊張型で, 断端部は両下肢共 㓔痕 $(-)$, 療着 $(-)$, 神経腫 $(-)$, 両上肢は㓔痕 $(-)$, 癒着 $(+)$, 神経腫 $(-)$ である。

下肢の幻肢は（図18-a) 変形縮少し, 毎日, 常 時存在し不動であるが，物事に熱中すると忘却す る。足趾は䟚趾だけに強く感じる。また断端部に 膝関節の部分があるような感じがするという。膝 関節は軽度屈曲したような感じがする。足関節は 感じられない。

幻肢痛としては右側幻肢全体に「じりじり」し た感じを訴える。

断端痛はない。

上肢の幻肢（図18一b）注左側には存在しない。 右側には示指のみに認めるが，幻肢痛はなく，ま た断端痛もない。心理治療により幻肢は上下肢共 消失し，8月15日性格的にヒステリー (正常)，男 性的，明型，緊張型となっている。

症例 19, 29歳令, 両下腿欠損（鉄道員，公傷） (図19)

昭和36年12月29日列車に両下腿を挾をれ，即日 
両下腿切断をうける。幻肢は約 1 力月間で消失し たが，強、断端痛を訴え，昭和37年 3 月 1 日右腓 骨神経腫摘出兼断端形成術をうけ，8月30日義足 装着。12月15日本院一入院した。12月24日両側断 端形成術兼神経腫摘出術を施行。昭和38年 5 月 14 日左股動脈交感神経切除術を行ない，12月16日退 院した。

昭和38年 4 月 10 日性格的には神経質 (異常 +3 ), 中性, 暗型, 弛緩型で, 断端部は両側共瘢痕 (-), 癒着 $($ 一), 神経腫 $($ 一) である。

幻肢はないが, 断端痛としてはなお刺痛, 絞把 痛, 「しびれ」感が著明で, ときどき電撃痛を訴 え, これは朝がもっとも強い。痛みを緩和する目

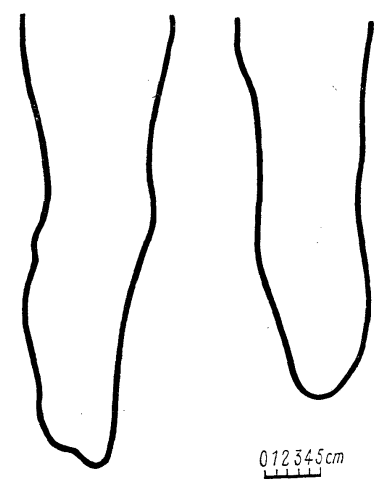

図19症例19，29歳す，両下腿欠損 性格: 神経質 (異常 +3 ), 中性, 暗型, 弛緩型 幻肢痛：なし

断端痛: 刺痛, 時々電撃痛, 絞扼痛, しびれ感

的で字を書いたり，ギターをひいて気分を安める ように努力する。本人の訴えとしては多くの切断 患者と話し合っていると, 自分の痛みの強いのは

「ノイローゼ」であると思われるので，一日も早 く社会復帰したいと願っていると述へている。本 症例では鎮痛剂々称して生理的食塩水の注射, あ るいは乳糖の屯服がいずれも効果している点から みても心理的な面が非常に強く働いている事が分 かる。またこの頃原職復帰への不安（仕事への自 信の消失）打よび家庭的不安とがそれぞれ同時に 重なり合った事も見逃せない。したがって安心し て社会復帰できる態勢にそれぞれ当事者に交渉を 行なったらえで，5月14日心理治療を含めた左股 脈交感神経切除術を行なった。7 月12日性格的に は神経質 (異常十 1), 男性的, 明型, 弛緩型とな
り, 断端痛は「しびれ」感, 硬直痛が主となり, 体位変換あるいは早期にときどき灼熱痛を訴える 程度となった。ついで強力な心理治療を含む整形 外科機能訓練を行なったところ，11月26日性格的 に神経質 (正常), やや男性的, 明型, 緊張型とな り，断端痛も消失した。

このように精神的不安といら事は疼痛と非常に 密接な関連性のある事が分かるとともに, 社会復 埽した場合に患者が置かれるであろら立場に対す る不安も見逃せない。したがって入院中いくら心 理治療を含むところの整形外科機能訓練を強力に 行ない, 機能回復とともに心理面の治療および疼 痛の消失を試みて成功しても, 社会の受け入れ態 勢が不充分であれば, 社会復帰後の本人の置かれ た環境のいかんによって，あるいはまた逆行する 恐劢が充分ある事も念頭におく必要がある。すな わちゆきとどいた社会保障の必要なゆえんでもあ る。

\section{III. 総 括}

以上四肢切断者 19例 (上肢欠損 5 例, 下肢欠損 13例, 多肢欠損 2 例）について, 幻肢の投影を行 ない，とくに幻肢痛を中心に検討したが3)4), 幻 肢痛はもちろん幻肢の存在する症例のうちに出現 するので，幻肢にすべて幻肢痛が伴らものではな い。また幻肢自体の消失は当然幻肢痛の消失をも 意味するものといえよう。したがって幻肢の消失 は大塚が試みた心理治療によって可能で, ここ $に^{7)}$ 述べた症例でも幻肢の消失した症例では，い ずれも幻肢痛の消失を同時に認めている。

上述のごとく幻肢痛は幻肢のあり方と非常に密 接な関連性をもっている事が分かるが，したがっ て一般に幻肢を強く感ずる場所に幻肢痛をまた強 く訴える傾向が窥われ，上肢欠損では日常感覚の 敏感な指尖で，しかも拇指に近づく程強く，また 下肢久損では前足部で幻肢に近い部位と踵部に幻: 肢および幻肢痛をそれぞれ強く感ずる傾向が窺わ れる。また切断前にあった創面などは幻肢にもそ の部位は強く残り，かつこの部の幻肢痛も強い。 幻肢は一般に中枢の映像が充分でない年少者や, 末梢部の用廃により中枢の映像が除々に薄れてい くような慢性用廃性疾患では心理治療により比較 
的早く消失し, したがって幻肢痛からも早く解放 される。

つぎに幻肢は屈曲位をとる場合が少なくない。

これは発生学的にみて, 我々の四肢ともに屈側 の諸筋群の方がその拮抗筋である伸筋群より.強 く，一般に長期臥床患者を放置した場合，この屈 曲位をとる事がしばしば知られている。このよう に中枢神経性の映像も屈筋群の方が，伸筋群のそ れよりむさらに強く影響を与えているためである うと推測したが7)，これと同時に幻肢を屈曲させ ると幻肢痛も軽快するという事も見逃せない。ま た幻肢が異常肢位をとると苦痛が増大するので， 幻肢痛から逃れるために，幻肢を楽な肢位に保つ 事も分った。これらの事実はまた大脳皮質の運動 領と知覚領との密接な関連性を示すものともいえ よう。

つぎに幻肢痛と断端痛との関係を追究してみる と，まず幻肢痛の疼痛内容としては「しびれ」感， 絞扼痛, 刺痛, 「じりじり」「ゔきゔき」「ぴりぴ り」「ちりちり」「ちかちか」, “電撃痛, 搏動痛,

「かゆみ」などが挙げられる。一方断端痛として はこれらのほかに灼熱痛, 圧潰痛などがあり，一 般にその疼痛内容はほぼ一致している事が分か る。幻肢は中枢性のもので，これを援護するのが 末梢性の諸因子（たとえば断端部の疲痕, 癒着, 神経腫など）であるというのが，我々の幻肢に対 する考え方であるが7)，幻肢が中枢性のものであ る以上幻肢痛ももちろん中枢性のものといえよ う。したがって幻肢痛と疼痛内容をほぼ同じくす る断端痛も中枢性のものと思われる。他方, 上述 の疼痛内容の形で表現される疼痛は中枢性疼痛と いわれ，視床の傷害の時にもその知覚障害として 現われるといわれる。

いずれにせよ幻肢痛は視床でキャッチされ11)， これが実際上疼痛として認識されるのは大脳皮質 の知覚領であるう。

つぎに幻肢痛と断端痛との関係を疼痛の強さの 面からみると, 幻肢痛は断端痛に優先していて， 幻肢痛を訴えている幻肢の部位が切断端より距離 間隔が充分離れている場合には，幻肢痛と断端痛 とは別々に感じているが，この間隔が非常に接近 した場合には幻肢痛と断端痛との区別は困難とな
ってくる。この場合, 幻肢痛と断端痛が同時に存 在していても，断端痛は幻肢痛にかくされる傾向 をきたす。また一般に幻肢痛がうすれるにしたが って（すなわち一般に幻肢が薄れるにしたがっ て）断端痛も軽減していく傾向を示している。し たがって幻肢，幻肢痛および断端痛の間にはその 消長にお互いに関連性が存在する傾向が窥われ る。

さて幻肢痛, 断端痛は精神的, 気象的影響をう けやすく, 感情に不安定な人に起こりやすく, 疼 痛は切断端の微刺激により誘発されるといわれて いるが11)，本症例でも幻肢痛および断端痛が，雨 天時, 寒冷時に増強し, また気分のいらいらした 不安状況や切断端の運動時にそれぞれ強く感じる 事は，この関係を裏ゔけるものといえよう。

一般に全身衰弱, 不安, 不眠があると疼痛を強 く感じ, また疼痛感覚には慣れの現象が見られな いで, 絶えず疼痛に会っていると，かえってそれ に敏感になってくるといわれている。

また断端痛は再生神経線維あるいは C 線維の興 奮 ${ }^{12)}$ により起こるといわれている。この意味にお いては切断に当たっては手術野13)の各組織の損傷 を必要最少限度に留め, とくに軟部組織の温存に 努め, 術後の化膿あるいは瘢痕拘縮, 神経腫発生 などを極力防止しなければならないのはもちろん であるが，同時に切断前後より早期に病棟におけ る心理治療を含む強力な整形外科機能訓練が必要 である。また疼痛の治療に当たって精神療法およ び物理療法もおろそかにできない事は事実で，再 生神経線維あるいは C 線維の興奮をとり除く ${ }^{14)}$ 一 手段として, マッサージや温熱13)療法も有効であ る。

一般に四肢切断者はその切断の直前ならびに切 断後は心理的に異常状態を示している場合が少な くない。とくに切断後幻肢のあったものにこの傾 向吕強く, 切断後 1 力年を経過しても, そのまま 放置した場合には性格的にもほぼそのままの性格 に固定してしまう傾向が椝われる。一方切断者は 本人の扔かる環境ならびに内因, 外因などによ り性格は変動し，なんらなすことなく放置する事 注患者の性格を暗く, また消極的として心理的に もっとも悪い。本症例においてもこの傾向が窥わ 
れる。一般に幻肢, 幻肢痛ならびに断端痛の強い 症例では性格の異常度も強く, 性格的にも暗く, また消極的なものが多く，これらの漸次消失して 行くにしたがって性格の正常化および積極性，明 るさを取り戻してくる傾向が窺われる。

したがって幻肢痛の消失(すなわち幻肢の消失) には心理治療を含む積極的な整形外科機能訓練が 必要となってくる。しかし一方では, 幻肢は可逆 性を有するので，一度消失したものでも再現も可 能で7)，患者自身のおかれる社会環境が悪くなる と幻肢は再現し，したがって幻肢痛も出現してく る可能性が充分にある。

この事は病院あるいは施設において心理治療を 含气整形外科機能訓練が行きとどいて，満足す心゙ き治療効果を得ていても，社会復帰後の本人のお かれる環境のいかんによっては再発する危険があ る事を意味しており，まず何よりも本人が精神的 にも肉体的にも安心して社会復帰できるような社 会保障の問題を含めた。社会の受け入れ態勢が充 分である事が要求される。

さて四肢切断者は幻肢のあるために義肢の装着 に障害をきたす場合が少なくなく，これはとくに 上肢切断者においていちじるしい。この事は一般 に非回復性疾患のリハビリテーションのあり方に とって大切な問題である。たとえば股関節の固定 術施行患者では，患者自身は術前の股関節運動が 可能であった時の状態が絶えず記憶に残っている ので，この股関節固定前の歩き方で歩行しようと するが，身体的には股関節は既に固定されてしま っているので，頭の中で考えているようには歩行 ができない。すなわち，あたかも四肢切断者の幻肢 と義肢とが一致しないで（症例８）参照，日常生活 に不自由をきたしているのと同じ状態となる。そ の結果疲労も強くなり，また種々疼痛発現の原因 ともなる。したがってこのような場合には，現在 固定されている股関節の歩行様式へと頭の切り替 え（所謂「洗脳」）を行なうとともに，身体の残 存能力の総動員と再調整とが必要となってくる。 これらは条件反射の理論にしたがって心理治療を 含む整形外科機能訓練により可能である。

したがって非回復性疾患については，その患者 の機能回復が将来最終的に扔かれるであるう。西
るいはまた，既にその最終的状態におかれている という事を充分考慮に入れたうえで，この状態に かなった心理指導を含む積極的な機能訓練が条件 反射の理論にしたがって行なわれる事が，ぜひと も必要となってくる。

いずれにせよ整形外科機能訓練に当たってはま ずその機能回復が大切である事は論を待たない が, さらに機能訓練には心理面および疼痛面もと もに関連性のある事に留意して訓練を行なう事が 大切である。な扮幻肢の問題についてはさらに脳 波, 筋電図等を使用して追究して行けばさらに興 味ある結果が得られるものと思われる。

\section{IV. 結 語}

以上主として公肢痛の問題を中心として検討を 行ない, 幻肢, 幻肢痛ならびに断端痛のあり方を 追究し, 幻肢と義肢との問題より，一部リハビリ テーションのあり方についても言及した。

（抒わりと臨み御校閲を賜わった院長塩津徳政博士 に深甚の謝意を表する)。

本文の要旨は昭和39年 7 月, 第 1 回日本リハビリ テーション医学会，総会の席上において述べた。

\section{引用文献}

1) 大塚・他：四肢切断者之幻肢，島根医学，2 巻 6号，9，1959.2) 大塚・他：四肢切断者の幻 肢 (多肢欠損者について), 整外と災外, 8 巻 2 号, 139，1959. 3) 大塚：手部切断者と幻肢, 日整会 誌，34巻 4 号，421，1960，4）大塚：幻肢之投影 図，日整会誌，35巻 1号，99，1961. 5) 大塚： 幻肢之性格，整外と災外，10巻 2 号，63，1961.

6) 大塚：四肢切断者之性格，整外之災外，11巻 2 号，52，1962. 7) 大塚：幻肢について，日整会 誌，37巻 1 号， $65 ， 1962.8)$ 大塚 - 他：四肢切断 者之疼痛, 災害医学, 7 巻 1 号, $57,1964$.

9) 小保内, 松岡：色彩象徴性格検查, 日本製版, （1956年11月，1959年4月）. 10）松岡：色彩象徵 法による Affectivemeaing の研究 (脱冕(反応) 色彩と性格異常), 山梨大学学芸部研究報告, 第14 号, 94, 1964. 11) 半田 - 他: 外科病態生理選書, 脳神経, 第 3 咕, 医学書院, 1960. 12) 山村: 疼 痛の治痖（ペインクリニーの中心として），日本医 師会雑誌，49巻 7 号，155，1963.13) 木村：疼 痛とその対策，外科治療， 7 巻 1 号，43，1962.

14）ポール・ションャール・樫尾沢：いたみ，白 水社, 1960 . 


\section{参考文献}

1) 平沢：大脳の最高中枢，日本医書出版，1961.

2) 平沢 : 脳と脊髄, 永井書店, 1955. 3) 坂本

・他訳：アルトン神経系の生理学，金芳堂，1960。

4) 児玉：カウザルギーと四肢断端の疼痛，診療， 10巻13号，1954. 5）宫城：性格,岩波新書, 1962.
6) 宮城: 夢, 岩波新書, 1962 . 7) 時実: 脳の 話, 岩波新書, 1963. 8) Henderson, W.R. and Smith, G. E. : phantom Limbs, J. Neurol \& psychit., 11, 88, 1948. 9) Herrmann, L. G. and Gibbs, E. W. : Phantom Limbpain, Am. J. Surg., 67, 168, 1945.

（昭和39年 7 月 21 日受付）
リハビリテーション医学が脚光を あびてきた今日，当然のことだが Physical Therapist (理学療法士 ; 略P.T.), Occupational Therapist (作業療法士 ; 略O.T.), Speech Therapist (言語療法士; 略 O. T.) などスタッフの問題が一つの大 きな課題となってきた。外国に留学 されたことのある方なら外国に和け る nurse の地位がいかに高いもの であるかを痛感されたことと思う が, P.T, O.T., S.T. も同様であ ろう。わが国和ける nurse のた どってきた茨の道を考光る時，そし てまた地位向上が叫ばれつつもなか なか到達し得ないことを考える時, せめて P.T., O.T., S.T.は始めか ら地位の高いものを一一すなわちレ ベルの高い教育をと望んでいたの に, P.T., O.T. の 3 年制の学校が 先にできてしまったことは残念であ る。東洋のうちでは文化が進んでい ると自称している日本と今まで $\mathrm{P}$. T., O.T., S.T. の教育課程がなか

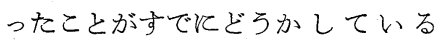
が，そのうえ 4 年制の大学課程のも のを作らず，専問学校を先に作り， それで間と合うから良いのだと思っ ている方々のいか反多いこと一一ま ったく嘆かわしい。すべては日本人 の性格とい拓うか，あるいは医者の 習性といったら過言であろうか, 教 育はなくとも安く雇っていう通りに 働いてくれる人を使いたいというと
ころから，こうなってしまつたのか もしれない。

私がある先生のところへ P.T., O.T. の資格のことで話をしに行っ た時, その先生はこうおつしゃっ た。「きみ，市えな字市が性しいの かい?」あえなるす்-P.T., O.T. はそれ程の価值しか認められていな いのである。手足を動かしてあげる

セラピストから

\section{セラピストの地位向上を}

のとは，何の知識もいらないという のであろうか。宍え字它をとるの 飞苦労するよりその人達を教育する 立場にたてと拈っしゃる。経験なく して教育ができるであろうか。P. T., O.T.は机の上だけの学問では ない。実践を伴わなければなんらそ の人，血となり肉とはならない学問 である。そしてその経験を得るのと 資格がなければならないとしたら 一。すなわち，あえな㐫性指導 者にとっても必要なものなのであ る。

一人の患者飞最低30分, 患者によ っては 2 時間もかけて，乙かも非常 に手がかかり一人で扱うのは無理な 場合すらあるが，それでも診療報酬
点数がたったの 6 点というのもひど い話である。一度に沢山訓練したか らといって良くなるものではなく， 実に根気のいる仕事である。脳卒中 の場合についていえば急に不具の身 となって意気消沈している患者を励 まし，いつまでも絶対安静を信じて いる患者や家族には新しい医学につ いて説明し, 四肢の変形, 裖瘡予防 などあらゆることに気を使いなが ら，目に見えない程の進歩と回復に 忍耐強く闘ってゆかね舛ならない。 そして，もうからない患者，医者之 して興味がない患者というので短期 間で退院させることを強いられ，せ っかくもう一歩というところで家に 帰されて，また逆房りしてしまった という苦い経験を多くのセラピスト が味わっているのである。てういう 患者は国家予算で特別の施設を作っ て扱竞ば良いことはいうまでもない ことであるが，それがない現在せめ てこういう治療の機会に恵まれた患 者だけにでもできるだけのことをし てあげるのが我々の任務と思う。

この学会の会員の先生方はこの分 野にはもちろ几理解のある先生方だ と思うので，むしろその他の先生方 に㹉いしていただきたいのだが， もっともっととの分野に理解を持 ち，セラピストのレベルを高めるこ とに力を大れて下さることを願って 止みません。

(K.O.) 